\title{
Introduction: Academic freedom in danger: case studies of Turkey, Hungary and Japan
}

\author{
Daniel Stockemer ${ }^{1} \cdot$ Mikyoung Kim $^{2}$
}

Published online: 25 May 2018

(C) European Consortium for Political Research 2018

In 1992, Francis Fukuyama famously predicts the "end of history." His famous thesis states that the installation of capitalist liberal democracy at the end of the Cold War in many parts of the world is the end point of human history. He argues that a democracy provides for harmonious interactions between citizens and the state and satisfies the needs of citizens; therefore, no capitalist democracies should ever see any need to revert back to any type of autocracy. Today, 25 years later, things are less rosy. Capitalist democracies are not the "only game in town" (Sin and Wells 2005). On the contrary, a Freedom House Report (2018) illustrates that roughly $39 \%$ of the world population live in a free state; this is only two percentage points more than the world population that lives in autocracies. ${ }^{1}$ In addition, 2017 is the 12 th consecutive year of a decline of global freedoms.

The contractions of democracy and human rights go hand in hand with the expansion of autocratic rule. In fact, few countries seem to be immune to the current nationalistic, populistic and autocratic tide that is sweeping the globe. As of 2018, superpowers including Russia and China are ruled by the iron fist of their respective dictators, Vladimir Putin and Xi Jinping; the latter has just been elected as president for life. Nationalist populist regimes have achieved and consolidated

\footnotetext{
1 The remaining $24 \%$ of the population live in so-called anocracies or partly free states.
}

Daniel Stockemer

dstockem@uottawa.ca

Mikyoung Kim

mkkim_33@hotmail.com

1 School of Political Studies, University of Ottawa, 120 University, Ottawa, ON K1N 6G2, Canada

2 Department of Russian and East Asian Languages and Cultures, Emory University, 201 Dowman Drive, Atlanta, GA 30322, USA 
powers in regional hubs such as Turkey, the Philippines and Venezuela. In the EU, the conservative governments of Poland and Hungary undermine the separation of powers and try to inhibit a free and fair media. Even the longest lasting democracy, the USA, is not immune from these autocratization tendencies. With the election of Donald Trump in 2016, the country has not only withdrawn from its role as a global promoter of democracy, its own democratic standards are also eroding quickly. Not only does Trump express friendship with some of the most loathsome leaders in the world, but the American President himself mingles personal business with state interests, appoints family members to senior government positions, treats judges and the media disdainfully and shows no respect for court orders (Freedom House 2018).

If democracy is in danger, then nearly by definition academic freedom is in danger, as well. There are many ways autocrats, populists or nationalists can attack academic freedom to sustain their power. In fact, academics are often the first target, if nondemocratic governments want to constrain freedom of speech and information. Nonconforming scholars might be discredited personally, they might be forced to teach a certain ideology or vision of the state, and they might be removed from their job, or in extreme cases taken to prison and tortured. Autocrats and populists might further discredit academic institutions as elitist and corrupted, shut them down or forcefully coopt these institutions. The rise of nationalism and populism in today's world alerts the members of the global academic community to the withering liberty in our enterprise. University campuses have become the site of culture wars where division, intimidation and politicking supersede the norms of unity, harmony and camaraderie.

The three essays of this symposium will exemplify how academics and academic institutions suffer, when under attack. The Turkish and Hungarian essays contextualize respective problems in macro sociopolitical milieus by suggesting that the weakening of democratic values is closely related to the contraction of academic freedoms. The essay on Japan shifts its focus to micro- and meso-level interactions between willful actors. The first essay by Ahmed Öztürk describes the prosecution of Prof. İştar Gözaydın, as one of many examples of Turkish academics, who are victims of the repressive and hegemonic ruling of the Development and Justice Party (AKP). Because she spoke up in favor of human rights, against the death penalty, and for a more humane handling of the Kurdish question, Gözaydın was fired from her job, arrested and held in prison for more than 100 days, under the pretext that she is a Gulenist conspirator. Up to this day, she is under house arrest and not allowed to leave Turkey. The second essay by Petra Bárd shows how a government that does not tolerate any internal dissent does not falter to pass a legislation to shut down one of the country's flagship universities, the Central European University (CEU). Bárd convincingly shows how the ruling Fidesz party pushed some modifications to the Act on National Education to the Parliament in order to force the US-accredited CEU out of Hungary. The last essay by Mikyoung Kim shifts the focus to a democratic setting, Japan, describing the litigation between Mikyoung Kim, a Korean woman tenured faculty and Hiroshima City University, a public university in Japan. The essay forcefully highlights how, even in a free state, academic freedom and human rights can be severely compromised at the hands of the powerful majority. Mikyoung Kim's story illustrates how the multilayers of discrimination, prejudice and violence manifest itself in the flagship university in the 'City of World Peace Culture.' 
The three essays exemplify the thousands of cases of blatant violations of academic freedom that happen every year around the globe. The rhetoric, 'academic freedom is the raison-de-tar of intellectual enterprise,' thus, does not stand the challenges of empirical reality. Many historical telltales point to the precarious waters that academics have to tread in the vicissitudes of political milieu. Academic freedom has never acquired the aspired state as its definition and praxis largely depend on the particulars and specifics of time and space.

For many of us, academic freedom is taken for granted given not only to receive state funding to advance science and knowledge, but also to talk freely about political, social or economic issues. Yet many of our colleagues might not enjoy these rights. The 'Varieties of Democracy Dataset' project, for instance, finds a very close correlation between sociopolitical equality and academic freedom where the OECD countries enjoy the highest levels of freedom in academic and cultural expressions (see Coppedge et al. 2017). That is followed by the South and East Asian regions. In contrast, Central Asia is the least free in expressing diverse academic and cultural values according to the project. Anytime we write an article or a book, give an interview or a commentary to the media or consult the government, we should be aware that some of our colleagues are denied of similar social services. We should also be vocal in our writings and media interventions of any infringement of academic freedom that we know of regardless of whether it happens at our own university or a university 10,000 miles away. After all, science and knowledge can only thrive to the fullest only if academics of all disciplines in all countries have the right to teach and speak up without the fear of discipline, demotion, termination or imprisonment regardless of their race, ethnicity, sexual orientation, religion, political affiliation or ideology. Only with heightened sense of self-vigilance in protecting and promoting the fundamental values that we should hold dear, can we sustain our raison-de-tar.

\section{References}

Coppedge, M., J. Gerring, S.I. Lindberg, S.-E. Skaaning, J. Teorell, D. Altman, M. Bernhard, M.S. Fish, A. Glynn, A. Hicken, C.H. Knutsen, A. Lührmann, K.L. Marquardt, K. McMann, V. Mechkova, P. Paxton, D. Pemstein, L. Saxer, B. Seim, R. Sigman, and J. Staton. 2017. V-Dem Codebook v7.1. Varieties of Democracy (V-Dem) Project.

Freedom House. 2018. Freedom in the World 2018. Democracy in crisis. Retrieved on March 26, 2018 from https://freedomhouse.org/report/freedom-world/freedom-world-2018.

Fukuyama, F. 1992. The end of history and the last man. New York: Free Press.

Sin, T.C., and J. Wells. 2005. Is democracy the only game in town? Journal of Democracy 16 (2): 88-101.

Daniel Stockemer is Associate Professor of Comparative Politics at the University of Ottawa and coeditor of European Political Science. His research interests are in the field of political behavior and political representation.

Mikyoung Kim is completing a book titled Korean memories: compressed modernity, psychohistorical fragmentation (forthcoming, Palgrave Macmillan). She is a member of two group research projects. One is on the 18 May, 1980 Kwangju Massacre in Korea and the other is on the absence of transitional justice processes in post-war Japan. Her book proposal on South Korean women textile factory workers in the 1970 s is under review by Routledge. 